\title{
ONLINE PIRACY OF INDIAN MOVIES: IS THE FILM INDUSTRY FIRING AT THE WRONG TARGET?
}

\author{
Arul George Scaria*
}

INTRODUCTION

I. ONLINE PIRACY OF INDIAN MOVIES.

II. EFFECTIVENESS OF THE LEGAL MEASURES AGAINST ONLINE

PIRACY

III. SuSTAINABLE SOLUTIONS FOR ONLINE PIRACY

CONCLUSION

\begin{abstract}
India has recently introduced some digital rights management (DRM) provisions to the Indian copyright law with the objective of providing "adequate" protection for copyrighted material in the online digital environment. Film industry was one of the biggest lobbying groups behind the new DRM provisions in India, and the industry has been consistently trying to portray online piracy as a major threat. The Indian film industry also extensively uses John Doe orders from the high courts in India to prevent the access of Internet users to websites suspected to be hosting pirated material. This paper explores two questions in the context of the new DRM provisions in India: (1) Is online piracy a threat to the Indian film industry? and (2) Are the present measures taken by the film industry the optimal measures for addressing the issue of online piracy? Based on data from an extensive empirical survey conducted in India, this paper questions the claims of the industry that online piracy is at a substantial level in India. The Internet usage related data in India also support the findings from the empirical survey. However, the paper observes that pirated Indian movie content is abundant in the Internet and this shows the existence of strong demand for those content. Based on a careful analysis of different websites hosting pirated Indian movies, the paper illustrates that the most probable consumers of those pirated movies are the millions of (potential) consumers residing abroad. The
\end{abstract}

* Post-doctoral Researcher, Center for Philosophy of Law - Biodiversity Governance Research Unit, Catholic University of Louvain (UCL), Belgium. Email: arul.scaria@uclouvain.be. The empirical data used in this study was collected as part of the doctoral research of the author at the International Max Planck Research School for Competition and Innovation, Munich, and the author thankfully acknowledges the financial support received from the Max Planck Society for the empirical survey. The author is also thankful to participants of the IP for Creative Upstarts conference (November 9-10, 2012) organised by the Michigan State University, particularly Professor Sean Pager, for insightful suggestions on the first draft of this paper. 
paper argues that the enactment of DRM provisions under Indian copyright law or wide sweeping John Doe orders may never be a solution for such piracy. Piracy of Indian movie content abroad is primarily attributable to the failure of the Indian film industry to explore innovative business models to reach (potential) consumers abroad. The paper argues that the Indian film industry may achieve sustainable solutions for online piracy only by making the legitimate products reach those consumers.

\section{INTRODUCTION}

Movies are an integral part of the cultural life of people in India and for millions of Indians they are also the only accessible and affordable form of entertainment. This vital role played by movies in the cultural life of people in India has also historically enabled the Indian film industry to play a critical role in the evolution of copyright law in India. ${ }^{1}$ The inclusion of long imprisonment terms and huge fines as remedies for copyright infringement under Indian copyright law is just one of the historical examples of the lobbying power of the film industry in India. ${ }^{2}$ While those remedies were included in the early 1980 s to overcome the challenges to the film industry from the emerging technologies of that time (VHS players and video cassettes), recent efforts from the film industry are aimed at addressing the challenges posed by the new digital technologies, particularly online piracy. As a result of intense lobbying over the past many years, the Indian Parliament recently amended copyright law to include some specific digital rights management ("DRM") provisions. The industry has also been highly successful in recent times in securing orders from the judiciary to prevent access of Internet users to many websites suspected to be hosting pirated movies. ${ }^{3}$

But is online piracy a threat to the Indian film industry? Are the present steps taken by the film industry the optimal measures for addressing the issue of online piracy of Indian media content? These are the primary questions addressed by this study in the context of the new DRM provisions and the highly pro-active approach of the judiciary in India. The study uses the mixed methods approach in research, which broadly refers to the use of both qualitative and quantitative components in a single study or in a series

1. The term 'Indian film industry' has been used in this study to refer to the regional film industries within India as a whole, and not just to Bollywood. The Indian film industry consists of different regional film industries and Bollywood represents only the Hindi language movies.

2. See The Copyright Act, 1957, No. 14, Acts of Parliament, 1957, §§ 63-63A, amended by The Copyright (Amendment) Act, 1984.

3. See Juhi Gupta, John Doe Copyright Injunctions in India, 18 J.I.P.R. 351, 353 (2013). 
of studies that investigate the same underlying phenomenon. ${ }^{4}$ The quantitative components in this study include data from an empirical survey conducted by the author in select parts of India. The qualitative components in the study include analysis of the copyright legislation and relevant case laws. The qualitative analysis also includes examination of the Internet usage related data and piracy related data using primary and secondary data sources.

This paper is organized as follows: This brief introduction is followed by Section II, which provides glances of diverging data on online piracy in India. While the first part of this section provides an overview of the industry data, the second part of this section provides an overview of the data from the empirical survey conducted by the author in India. This section also analyses the availability of pirated Indian movie contents online and the potential consumers of the same. Section III analyses the effectiveness of the new legal provisions and the approaches of the Indian judiciary with regard to online piracy, in the background of the findings in Section II. Section III puts forward some pragmatic suggestions for the Indian film industry to address the issue of online piracy in a sustainable way. The paper concludes with some closing remarks.

\section{ONLINE PIRACY OF INDIAN MOVIES}

Like most other film industries across the world, the Indian film industry relies extensively on media and industry-sponsored studies for arguing that online piracy is substantial in India. ${ }^{5}$ The most remarkable among such studies, which projects the views of the Indian film industry on online piracy, is India: Internet Piracy Landscape Audit, conducted by Envisional and the Motion Pictures Association (hereafter referred to as "MPA study"). ${ }^{6}$

The MPA study claims that online piracy of movie content is significant in India. ${ }^{7}$ According to the MPA study, Indians are the largest group of visitors to the Indian content-focused torrent sites, and they also constitute the largest or second largest group of people who visit the five major

4. Nancy L. Leech \& Anthony J. Onwuegbuzie, A Typology of Mixed Methods Research Designs, 43 Quality \& QuANTITY 265, 267 (2009).

5. See Press Release, Online Piracy a Genuine Threat to the Indian Film \& Television Industry, Motion Pictures Association Asia Pacific (Dec.15, 2009), available at http://mpa-i.org/index.php/news/online_piracy_a_genuine_threat_to_the_indian_film_televis ion_industry/ (last visited Oct. 15, 2012); India Among top 10 in Online Piracy; Television, Film Industry Take a Hit, THE FinANCIAL EXPRESS, December 16, 2009, http://www.financia lexpress.com/news/indiaamongtop10inonlinepiracy\%3Btelevision-filmingdustrytakeahit/554 531(last visited Oct. 19, 2012).

6. EnVisional \& Motion Pictures Association, India: InTERnet Piracy LANDSCAPE AUDIT (2009).

7. Id. at 3-4. 
international bit-torrent sites. ${ }^{8}$ The five major international bit-torrent sites mentioned in their report are Mininova, Torrentz, Thepiratebay, Isohunt, and Btjunkie. While Indians are found to be the largest group of visitors in torrentz, they are reported as second only to those from the U.S. in the remaining four. ${ }^{\text {The }}$ MPA study also provides some interesting data regarding the downloading of pirated movies. They claim to have tracked the IP addresses of computers that downloaded six Hollywood movies. ${ }^{10}$ Their data show that Indians constitute the fourth largest group, with 6.5\% of the total downloaders. ${ }^{11}$ Based on a comparative analysis, the MPA study claims that India has the highest levels of broadband piracy relative to number of broadband subscribers. ${ }^{12}$

The MPA study also provides some data regarding the illegal downloading of Bollywood movies. ${ }^{13}$ It provides estimates regarding the illegal downloading of some movies during the four weeks from which a pirated copy was available, and argues that illegal downloads are substantial in India. ${ }^{14}$ According to their report, one of the movies in their analysis, Kaminey, was downloaded more than 350,000 times on BitTorrent and twothirds of the download could be traced to locations within India. ${ }^{15}$ The study claims that the illegal downloading of Bollywood movies are mostly from Delhi, Bangalore, and Mumbai. ${ }^{16}$

The MPA study also makes some interesting estimates regarding the use of cyberlockers for piracy in India. It mentions that "[E]nvisional believe (emphasis added) that there are around 2 million regular users of such sites worldwide" and Indians are one of the largest users of cyberlockers. ${ }^{17}$

8. Id. at 10 . The report mentions that they conducted this analysis using Alexa, one of the web-services that provide web traffic data of different websites.

9. Id. at 11 .

10. The six Hollywood movies they tracked are Transformers: Revenge of the Fallen, The Proposal, Angels \& Demons, Star Trek, Night at the Museum and The Dark Knight. Id. at 31. It may be noted here that the rationale used for the selection of movies is not mentioned in the study.

11. Id. at 13 .

12. Id. at 14 . The study mentions that $0.76 \%$ of the 7 million broadband customers in India were detected to have downloaded at least one of the six pirated movies during the four week monitoring period. The study mentions that the ratio of the same was $0.7 \%$ in Canada, $0.5 \%$ in Great Britain, $0.44 \%$ in Australia, and $0.18 \%$ in the US. Id.

13. Id. at 18-19. The movies monitored are Rab Ne Bana Jodi, Luck, Love Aaj Kal and Kaminey. The study does not mention the reasons behind the selection of these four movies.

14. Id. at 19 .

15. See also, India among top 10 in online piracy; television, film industry take a hit, THE FINANCIAL EXPRESS, supra note 4.

16. Id. at 18-19. See, also, Online Piracy a Genuine Threat to the Indian Film \& Television Industry, Motion Pictures Association Asia Pacific-Pacific Press Release, supra note 4.

17. Envisional \& Motion Pictures Association, India, supra note 6, at 25 . 
According to their data, Indian users constitute $8.2 \%$ of the visitors to the top ten cyberlockers in the world. ${ }^{18}$

But there are a few factors to consider while interpreting the data from the MPA study and also the enormous number of media reports based on findings from that study. The most important among them is the lack of transparency in the methodology used for many of the estimates in the study. ${ }^{19}$ This makes it difficult, if not impossible, to replicate the experiments for verification of data. Second, the data with regard to the percentage of visitors to different torrent sites has to be subscribed very carefully. For example, this author attempted to replicate the analysis on different popular websites, using the same data source (Alexa) mentioned in the MPA study. Interestingly, even for websites like amazon.com, which has yet to have a commercial presence in India, Alexa data show visitors from India as the second largest group. ${ }^{20}$ This clearly indicates the fact that no valid inferences can be drawn about the purpose of access to a website, merely from the data on the proportion of visitors to that website. Third, with regard to data on downloading, the study is silent about critical aspects like methodology used for the estimates, time period of analysis, and tools used for tracking, thereby making it impossible to verify or replicate the study. Finally, with regard to the data on cyberlockers, it may be noted that cyberlockers also have many lawful uses and it is hard to imagine that all those who visited cyberlockers (even assuming for a moment that their data with regard to visitors were accurate) are visiting them for illegal file access. To summarize, the data on online piracy in India, provided by the film industry, needs to be adopted carefully and the film industry must try to make the methodologies in future studies more transparent.

The lack of data on the nature of piracy in India and the attitude of people in India towards piracy had prompted this author to undertake an independent empirical survey in India, as part of his doctoral research. Exposure of consumers to online piracy, both in streaming and downloading movies, was one of the important dimensions explored in this regard. The empirical survey was conducted during the months of August and September in the year 2010 using Pencil-and-Paper based questionnaires. ${ }^{21}$ In order to meet the dual challenge of capturing the diversity of India and

18. Id. at 26 .

6.

19. See generally, EnVisional \& Motion Pictures Association, India, supra note

20. Percentage of visitors to www.amazon.com from the top three countries on the data of experiment was found as follows - US: $63.5 \%$, India: $3.2 \%$, and UK: $2.8 \%$. See STATISTICS SUMmaRY FOR AMAZON.COM, http://www.alexa.com/siteinfo/amazon.com (last visited Jan. 21, 2011).

21. Though web-based surveys are far more convenient and easier to administer, it had to be avoided in this study, as most of the under-graduate educational institutions in India, particularly those in the rural areas, do not provide their students institution based email addresses or maintain any database of email addresses of their students. 
the administration of a single questionnaire in all parts of India, the sampling method used in the survey was stratified purposive sampling, which refers to the category of purposive sampling that illustrates subgroups and facilitates comparisons. ${ }^{22}$ The survey was conducted among undergraduate students from four different streams of studies (arts, science, law, and technology) in institutions located in three types of locations (cities, towns, and villages). ${ }^{23}$ While the use of a student sample often brings in limitations with regard to external validity, it was substantially helpful in this study, as students constitute one of the most important segments of movie consumers in India. ${ }^{24}$ Students are also generally the ones with the most exposure to technology, but limited financial resources for accessing movies in legitimate channels. A total of 600 questionnaires were distributed on different campuses as part of the survey, and 491 responses were received. ${ }^{25}$

The data from the empirical survey reveal interesting aspects regarding the exposure of Indian society to online piracy. One may first look at the data regarding exposure to streaming of pirated movies. Only a total of $27.99 \%$ of the respondents are found to have streamed at least one pirated movie during the three months preceding the survey, thereby indicating that streaming of pirated movies is not yet widely practiced in India. The data on downloading pirated movies show that only $30.23 \%$ of the respondents have downloaded at least one pirated movie during the same time period. One may compare these figures with the percentage of the respondents who are found to have watched at least one pirated movie VCD/DVD during the same time period of analysis-53.94\%. This indicates that movie piracy in India is still dominated by offline channels.

Categorical analysis of the data on online piracy provides some important additional insight. For example, categorical analysis based on the type of location of the respondents shows that the exposure to online piracy is considerably higher in urban areas, as compared to rural areas in India. While $41.74 \%$ of the respondents from the city category and $33.08 \%$ of the

22. For detailed discussion on stratified purposive sampling, see MATtheW B. MiLes \& Michael Huberman, Qualitative Data Analysis: An ExPanded Sourcebook 28 (Sage Publ'n. 1994). The biggest challenge for administering a single questionnaire in all parts of India is the huge linguistic diversity in India.

23. To ensure the methodological rigour in this process, the definition of 'villages', 'towns', and 'cities', followed in the Census of India 2001, was adopted for identifying different types of locations.

24. More than $50 \%$ of the domestic theatrical revenues for Bollywood movies are received from people in the age group of 18-30. Abhilasha Ojha and Gouri Shah, Bollywood Production Houses Target Youth to Script Success, LivemEnT, May 27, 2011, available at Westlaw.

25. Fourteen of them had to be discarded after the initial scrutiny. Among the fourteen discarded, six were discarded as they were from post-graduate students and eight were discarded as those respondents never watched movies. They were identified on the basis of their response to the screening questions included in the questionnaire. 
respondents from the town category are found to have streamed at least one pirated movie during the preceding three months, only $12.41 \%$ of the respondents from the village category are found to have engaged in the same during the same time period. ${ }^{26}$ Similarly, while as high as $49.23 \%$ of the respondents from the town category and $33.33 \%$ respondents from the city category are found to have engaged in downloading of pirated movies during the same time period of analysis, only $10.49 \%$ of the respondents from the village category engaged in the same. ${ }^{27}$

Categorical analysis based on educational background show that exposure to online piracy varies substantially between people from different educational backgrounds. Exposure to online piracy is found to be highest among those from the technology background. While $31.07 \%$ of the students from the technology background are found to have streamed at least one pirated movie during the three months preceding the survey, only $17.19 \%$ of the students from science backgrounds are found to have similar exposure. ${ }^{28}$ Similarly, while as high as $50.93 \%$ of the respondents from technology backgrounds are found to have downloaded at least one pirated movie during the three months preceding the survey, only $11.11 \%$ of the respondents from science backgrounds are found to have engaged in the same. ${ }^{29}$

Categorical analysis of the data based on gender shows a substantially higher percentage of males engaging in online piracy, as compared to females. While $34.06 \%$ of males are found to have streamed at least one pirated movie during the preceding three months, only $16.89 \%$ of females are found to have engaged in the same during the same time period. ${ }^{30}$ Similarly, when one looks at the data on illegal downloading, it shows that $38.5 \%$ of males have downloaded at least one pirated movie during the preceding three months, as compared to $17.93 \%$ of females. ${ }^{31}$

26. The Wilcoxon rank-sum test shows that the differences between cities and villages $(\mathrm{z}=5.463, \mathrm{p}<0.001)$ and the differences between towns and villages $(\mathrm{z}=4.102$, $\mathrm{p}<0.001)$ are statistically significant.

27. The Wilcoxon rank-sum test shows that the differences between cities and towns $(\mathrm{z}=-2.108, \mathrm{p}=0.035)$, between towns and villages $(\mathrm{z}=7.1222, \mathrm{p}<0.001)$ and between cities and villages $(\mathrm{z}=4.688, \mathrm{p}<0.001)$ are also statistically significant

28. The Wilcoxon rank-sum test shows that the differences between arts and science $(\mathrm{z}=2.177, \mathrm{p}=0.03)$ and between science and technology $(\mathrm{z}=-2.043, \mathrm{p}=0.041)$ are statistically significant.

29. The differences between arts and technology $(z=-3.930, p<0.001)$, between science and technology $(\mathrm{z}=-5.186, \mathrm{p}<0.001)$, between law and technology $(\mathrm{z}=-4.054$, $\mathrm{p}<0.001)$, between arts and science $(\mathrm{z}=2.463, \mathrm{p}=0.014)$, and between law and science $(\mathrm{z}=1.983, \mathrm{p}=0.047)$ are found to be statistically significant in the Wilcoxon rank-sum test.

30. The Wilcoxon rank-sum test shows that the diff erences between the genders are statistically significant $(\mathrm{z}=-3.641, \mathrm{p}<0.001)$.

31. The Wilcoxon rank-sum test shows that the differences are statistically significant $(\mathrm{z}=-4.293, \mathrm{p}<0.001)$. 
Two important aspects are particularly visible from a combined reading of the data. First, the percentage of respondents who have engaged in online piracy (streaming or downloading pirated movies) is far less when compared to the percentage of respondents who have engaged in offline piracy (watching pirated movie VCD/DVD). This challenges the claims of the industry that online piracy is substantial in India today. The data from a recent study conducted by KPMG, wherein it is reported that piracy in India is primarily channeled through around 10,000 vendors, also supports the finding from the present survey. ${ }^{32}$ The Internet usage related data, particularly the nature of internet access points and speed/costs of broadband connections in India, also point more towards the possibility that online piracy may not be at a substantial level within India. ${ }^{33}$

Second, as evident from the categorical analysis of the data, exposure to online piracy within India varies considerably. For example, as the data described above show, people from the urban areas and those from the technology background have considerably higher exposure to online piracy. Similarly, males are found to have considerably higher exposure to online piracy as compared to females. There could many more faces of diversity like income, state, language, etc. Any data on online piracy in India that conceals this diversity aspect may only be bringing a distorted picture of piracy. The diversity aspect also shows the need for more focused campaigns from the side of the industry, if the industry wishes to reduce online piracy within India.

Finally, it is also important to observe that the domestic theatrical revenues of the Indian film industry do not show any correlated decreases in revenues corresponding to the increases in Internet connections and Internet users in India. On the contrary, domestic theatrical revenues for the film industry are seen moving in an upward direction, in spite of the increase in the number of Internet users in India. For example, the total revenues of the film industry have increased from INR 83.3 billion in the year 2010 to INR 92.9 billion in the year $2011 .^{34}$ The industry is also projected to have a combined annual growth rate of $10.1 \%$ during the period from 2011 to $2016 .{ }^{35}$ Even the music industry, which is portrayed by many as the biggest victim of piracy, shows a similar picture of growth in revenues in India. The Indian music industry has witnessed an overall increase in revenues from

32. Hitting the High Notes: FICCI-KPMG Indian Media \& Entertainment Industry Report 2011, KPMG 63-64 (2011) [hereinafter KPMG], http://www.kpmg.com/IN/en/Issues AndInsights/ThoughtLeadership/FICCI-KPMG-Report-2011.pdf.

33. For a critical discussion in this regard see Arul George Scaria, Does India Need Digital Rights Management Provisions or Better Digital Business Management Strategies?, 17 J. INTELL. PROP. RTS. 463, 470-472 (2012).

34. Digital Dawn: The Metamorphosis Begins: FICCI-KPMG Indian Media \& Entertainment Industry Report 2012, KPMG 61 (2012), http://www.kpmg.com/IN/en/Issues AndInsights/ThoughtLeadership/Report-2012.pdf.

35. Id. 
INR 8.6 billion in the year 2010 to INR 9 billion in the year $2011 .{ }^{36}$ But the most interesting factor that one may notice while analysing the combined annual growth of the music industry during the years 2007 to 2011 is that there has been a substantial reduction in the sale of physical media $(-17 \%)$ along with a drastic increase in the sale of digital media $(+39 \%) \cdot{ }^{37}$ This clearly indicates a major change in consumer preferences and any decline in the sale of physical media in music may only be indicating changing consumer preferences.

While the discussion above points more towards the possibilities of low rates of online movie piracy within India, it does not in any manner suggest that online piracy of Indian movies is negligible. In fact, any search engine can show thousands of pirated Indian movie files spread across the web. In many cases, the pirated versions of the movies are also released online on the same day or the very next day of release of the movie in cinemas. ${ }^{38}$

As most economists would agree, the demand for a product has a substantial role in increasing the supply of that product in the long run, and the same should be true in the case of pirated movies. This leads to the puzzling question of who are the primary consumers of Indian pirated movies available online. While the Indian film industry has always been targeting the movie consumers within India, this study would like to take a differing position in this regard, particularly against the backdrop of the findings from the empirical survey and also the Internet usage related statistics in India. This study is of the view that it is more likely that the primary consumers of those online pirated products are millions of Indian movie consumers living abroad. There are a few factors that makes one reach this hypothesis.

First, India is one of those countries with a fairly large diaspora. The latest available official estimates consider the number of Indians living abroad as nearly 22 million. ${ }^{39}$ Like most Indians living within the territory of India, Indians abroad are also potential or regular consumers of Indian movies. Apart from Indians living abroad, one should also take into consideration the fairly large number of non-Indian consumers of Indian movies abroad, particularly in other South Asian and Arab countries. But as one may notice from the industry data, overseas revenues for the Indian film industry are still negligible when compared to domestic revenues. ${ }^{40}$ This is

36. Id. at 117 .

37. Id.

38. One of the recent examples in this regard is the movie English Vinglish, which was released in India on October 5, 2012. See http://www.imdb.com/title/tt2181931/releasein fo (accessed October 17, 2012). Enormous number of links to the pirated versions of this movie was available from the very next day, October 6, 2012.

39. Data as on May 2012, available at http://moia.gov.in/writereaddata/pdf/NRISPI OS-Data\%2815-06-12\%29new.pdf (last visited Oct. 17, 2012).

40. Digital Dawn: FICCI-KPMG Indian Media \& Entertainment Industry Report 2012, supra note 34 , at 63 . 
hardly surprising as the Indian film industry still limits its focus to cinema releases as the primary source of revenues from abroad.

While the industry earned INR 62 billion in the year 2010 from domestic cinemas, overseas cinemas contributed just INR 6.6 billion. ${ }^{41}$ Similarly, while the industry earned INR 68.8 billion in the year 2011 from domestic cinemas, it earned just INR 6.9 billion from overseas cinemas. ${ }^{42}$ One may note here that the number of Indian movies released in cinemas abroad is far less compared to the number of movies produced in India and the number of potential consumers living abroad. While the number of screens abroad in which big budget movies are released has increased to 400-500 screens in the year 2011 from 250 screens in the year 2010, the number of screens remains at around 100-120 for medium and small budget movies. ${ }^{43}$ The limited number of cinema releases abroad is a particularly serious issue for the movies from regional film industries in India other than Bollywood. While many of the regional film industries like Tamil and Telugu produce large number of movies, their overseas cinema releases are far less when compared to Bollywood, in spite of the fact that they also have similar number of (potential) consumers abroad. ${ }^{44}$

One should also note that other legitimate channels that provide access to Indian movies for consumers abroad are limited even today, in spite of the enormous potential of the market and the opportunities provided by the digital technologies. During earlier times, the neglect of the market could have been attributed to the enormous costs involved in producing and circulating film prints in overseas markets and the resulting financial risks the producers had to undertake. ${ }^{45}$ But such excuses do not exist today, in view of the possibilities of current digital technologies to reach consumers directly at reasonable costs. During the earlier times, the pirates had played a major role in making the Indian movies reach the neglected overseas markets through playback technologies like video cassettes and the "Indian" grocery shops abroad had a prominent role as the intermediary channel. ${ }^{46}$ However, with the emergence of Internet and online sharing platforms, the

41. $I d$.

42. Id.

43. Data as on 2011. Id.

44. According to the 2011 film certification data, 192 Telugu movies and 185 Tamil movies were certified for release in the year 2011. One may compare this to 206 Bollywood movies certified during the same time period. CENTRAL BOARD OF FILM CERTIFICATION, ANNUAL REPORT 2011, 18, available at $\mathrm{http} / / / \mathrm{cbfcindia.gov.in/html/uniquepage.aspx?unique}$ _page_id=30 (last visited Oct. 18, 2012).

45. Adrian Mabbott Athique, The Global Dynamics of Indian Media Piracy: Export Markets, Playback Media and the Informal Economy, 30 Media, Culture \& SoC'y 699, 703 (2008); see also Adrian Mabbottt Athique, Bollywood and 'Grocery Store' Video Piracy in Australia, 121 Media InT'L Austl 41, 41 (2006).

46. See generally Atique, Bollywood and the 'Grocery Store' Video Piracy in Australia, supra note 45 (providing an interesting discussion on 'grocery store' based piracy of Indian movies in Australia). 
only major change that has happened is the replacement of those intermediaries to a great extent, as pirates can reach most consumers directly now. This may continue as long as the film industry ignores the digital opportunities for reaching consumers abroad.

A careful analysis of some of the major websites providing access to pirated Indian movies also supports the view that the primary audiences of most of these websites are consumers living abroad and not those within India. ${ }^{47}$ Three observed factors need to be specifically mentioned in this regard. First, analysis of the nature and topics of discussion in the chat forums in many of the online pirated movie portals show that the forums are dominated by non-resident Indians. ${ }^{48}$ Second, the business models used by most of the hosting websites show that they are operating from abroad, primarily on donations from viewers. ${ }^{49}$ For example, both the payments to the contributors of pirated copies and the request for donations from consumers (of those pirated copies) are in U.S. Dollars and not in Indian Rupees. ${ }^{50}$ If the primary consumers of those movies were those residing within India, the transactions would have been in Indian Rupees, as transactions in foreign currencies are subject to high level of monitoring by the central bank in India. Third, location analysis of the IP addresses of popular pirated Indian movie websites show that most of them are located outside India, with most of them in the U.S. ${ }^{51}$ Finally, when one reads these facts in the context of data from the empirical survey discussed earlier, which show that the exposure of consumers within India to online pirate media is minimal when compared to offline pirate media, it reveals the strong possibility that the primary consumers for online pirated movies are Indian movie consumers living abroad and not those residing within India.

\section{EfFectiveness of the Legal Measures Against OnLINE PIRACY}

As mentioned earlier, the film industry has always been a powerful lobbying group in the legislative process in India, both at the national and the state levels. While the Constitution of India has vested the legislative competence on copyright related matters with the Parliament of India, different regional film industries in India have been successful in forcing many state legislatures to legislate on the subject of copyright through

47. See also Scaria, supra note 33 , at 471 .

48. See, e.g., MALLuvision.ORG, Chat Forum,(last visited Feb. 2, 2010), www.mallu vision.org.

49. Id

50. Id.

51. IP ADDRESS.ORG, www.ip-address.org (last visited Jan. 19, 2013). See, e.g., STREAMING Bollywood, www.streamingbollywood.com; HINDI-MoviE.OrG, www.hindimovie.org; INDIA TERMINAL, www.indianterminal.com. 
indirect paths. ${ }^{52}$ Several anti-piracy legislation at the state level, including those allowing for preventive detention of suspected infringers, illustrate the lobbying power of different regional film industries at the state level in this regard. ${ }^{53}$ But the new DRM provisions show the power of the film industry at the national level. ${ }^{54}$

The Copyright (Amendment) Act 2012 added two DRM Provisions. ${ }^{55}$ The first provision deals with protection against circumvention of technological measures. According to this provision, if any person circumvents an effective technological measure used for the purpose of protecting any of the rights conferred under the Copyright Act, with the intention of infringing such rights, he or she shall be punished with imprisonment which may extend up to two years and will also be subjected to a monetary fine. ${ }^{56}$ The second provision deals with protection of rights management information and according to this provision, if any person knowingly removes or alters any rights management information without authority, he or she shall be fined and imprisoned for up to two years. ${ }^{57}$ Similar punishments are also prescribed for persons who distribute, import for distribution, broadcast or communicate to the public, copies of any work or performance without authority, knowing that the rights management information has been removed or altered without authority. ${ }^{58}$ The new provisions also specifically mention that the criminal remedies provided are in addition to the civil remedies already provided under copyright law for the copyright owners in such works. ${ }^{59}$

As evident from the debates on these provisions in the Parliament as well as the statement of objects and reasons in the Bill introduced in the Parliament, the primary objective of the new provisions were combating digital piracy and facilitating India's membership in the WIPO Copyright

52. See Art. 246 of the Constitution of India and List - I of the Seventh Schedule of the Constitution of India.

53. See, e.g., Kerala Anti-Social Activities (Prevention) Act, 2007, No. 34, Acts of Parliament, 2007 (India). Copyright piracy for commercial purposes comes within the purview of 'anti-social activities' and a person who is engaged in such activities comes within the definition of a 'Goonda', a term which is commonly used for referring extreme antisocial elements in the society. Id. Sec. 2(h) defines copyright pirate, Sec. 2(a) defines anti-social activity and Sec. 2(j) defines goonda. This legislation allows such persons to be detained for a period of up to 6 months. See Sec. 12 of the Act. See also T. Prashant Reddy \& N. Sai Vinod, The constitutionality of preventing "video piracy" through preventive detention in Indian states, 7 J. INTELL. Prop. L. \& PRAC. 194, 194-204 (2012).

54. For detailed discussion on the new DRM provisions in India, See Tarun Krishnakumar \& Kaustav Saha, India's new copyright law: the good, the bad and the DRM, 8 J. InTEll. Prop. L. \& PraC. 15, 15-17 (2013). See Scaria, supra note 33, at 463-477. 37).

55. See The Copyright (Amendment) Act, No. 27 of 2012, India Code (2012)(Sec.

56. See The Copyright Act, No. 14 of 1957, India Code (1957)(Sec. 65(A)(1)).

57. Id. at Sec. 65B (i).

58. Id. at Sec. $65 \mathrm{~B}$ (ii).

59. Id. at Proviso to Sec. 65B. 
Treaty (WCT) and the WIPO Performers and Phonograms Treaty (WPPT) ${ }^{60}$ As the debates show, the primary argument of the drafters of the new provisions was that harmonisation of the Indian copyright law with the two WIPO Internet treaties was necessary and desirable for India to extend adequate protection for copyrighted material in inter-connected digital world. ${ }^{61}$

One must also try to see the new DRM provisions in the context of the highly over-reaching approach already taken by the judiciary in India with regard to online piracy. The most important among them is the wide spread use of John Doe orders (or Ashok Kumar orders in the Indian judicial parlance), without providing adequate attention to the potential impact of such orders on legitimate Internet uses and users. The term John Doe order refers to orders where the identities of defendants are unknown at the time of filing of the petition and the orders identify the defendants only by way of some description. ${ }^{62}$ The producers in the Indian film industry make extensive use of this form of judicial intervention against online piracy by filing such applications before the release of new movies. ${ }^{63}$ While John Doe orders should be granted only under the most necessary and strictest conditions in view of its potential impact on legitimate uses/users, many high courts in India can be seen granting such orders without any precautionary measures to protect the legitimate online uses and Internet users. The right holders use broadly worded John Doe orders as a tool for forcing the Internet Service Providers (ISP) to block entire websites suspected to be providing access or links to pirated content online and the ISPs often succumb to such pressure from the right holders, in fear of

60. The Copyright (Amendment) Act, supra note 55, at 14-15; see also Rajya Sabha, Verbatim Debates (17 May 2012, 20:00PM to 21:00PM), 3-4, available at http://164.100.47 $.5 /$ newdebate/225/17052012/20.00pmTo21.00pm.pdf (last visited May 27, 2012).

61. Id. at 4

62. Tanushree Sangal, Piracy in the Media and Entertainment Industry in India: Stemming the Menace, 20 ENT. L. R. 82, 85 (2009). While such judicial interventions can be found in many other jurisdictions also, the legal roots of such approach in India can be traced back to the year 2002, wherein the High Court of Delhi issued an order for preventing the illegal broadcasting of the World cup 2002. See Pravin Anand \& Nikhil Krishnamurthy, India: Trade Marks in a State of Change, Managing Intell. Prop., (Jan. 1, 2003), http://www.managingip.com/Article/1321770/India-Trade-marks-in-a-state-of-change.html.

63. See, e.g., Swati Deshpande, Film gets HC shield against piracy, THE TIMES OF INDIA, (June 16, 2012), http://articles.timesofindia.indiatimes.com/2012-06-16/mumbai/3226 8729_1_hc-shield-film-john-doe; Vasudha Venugopal, Internet users enraged over blocking of file-sharing sites, THE HINDU, (May 18, 2012), http://www.thehindu.com/news/cities/chen nai/article3429836.ece; Prashant Reddy, Madras High Court passes its first-ever 'John Doe' order, SPICY INTELL. PROP. BlOG (Mar. 30, 2012, 2:36 am), http://spicyipindia.blogspot.be/2 012/03/madras-high-court-passes-its-first-ever.html; Express News Services - Chennai, Relief for Maattrraan, THE NEW INDIAN EXPRESS, (Oct.13, 2012), http://newindianexpress.co m/entertainment/tamil/article1297176.ece. 
violation of court orders. ${ }^{64}$ This has many a times affected legitimate Internet uses. ${ }^{65}$

While it is a fact that there is widespread availability of pirated Indian media products online, neither the new DRM provisions enacted by the Parliament nor the John Doe orders from the Indian judiciary are solutions to such piracy. One may take into consideration two important aspects in this regard. First, as discussed in the previous section, if the primary consumers and hosts of online pirated Indian movies are mostly abroad, enactment of DRM provisions under the Indian copyright law will never be a solution to such piracy, considering the territorial limitations of copyright law. The same territorial limitations of copyright law also limit the reach of John Doe orders to Internet Service Providers within India. Second and more importantly, piracy of Indian movies products abroad is primarily attributable to the failure of the Indian film industry to serve those markets with legitimate products. For example, as illustrated in the preceding section, the number of cinemas in which Indian movies are released abroad are far less when compared to the number of (potential) consumers living abroad and the number of movies produced in the Indian film industry. More importantly, the Indian film industry is also failing to use the opportunities provided by the new digital technologies to deliver contents securely, quickly and directly to their (potential) consumers abroad. As long as the industry fails to provide those consumers with legitimate access options, one should expect more pirates to enter this lucrative, yet neglected, market.

\section{SUSTAINABLE SOLUTIONS For ONLINE PIRACY}

It is hard to substantiate the monetary loss caused by online piracy of Indian media content abroad, as the industry is currently serving this market only in a very limited way. Since hardly any sales displacements are happening, it is hard to agree with the views of the industry that Internet piracy is causing substantial loss to the Indian film industry. But merely because Internet piracy within India is currently not that substantial, does it necessarily mean that online piracy cannot be a threat for the Indian film industry? With more affordable and better broadband Internet connections,

64. Id.

65. The imposition of fines on an ISP by a consumer redressal forum in one of such illegitimate blocking incidents illustrate the gravity of the issue. See Vinay B v. Airtel Authorized Representative, (2012) 226 C.C. 1, 9-10 (India), available at http://164.100.72.12 /ncdrcrep/judgement/18533120803153733968226-202.pdf. In this case, the District Consumer Redressal forum in Shimoga (Karnataka) was imposing fines on Airtel, one of the most prominent internet service providers in India, against the indiscriminate blocking of torrent websites in the name of a John Doe order issued by the Madras High Court. Id.; See also, Anuj Srivas, Airtel penalised for 'torrent site' block, legality questioned, THE HINDU, (Aug. 7, 2012), http://www.thehindu.com/sci-tech/internet/article3738269.ece. 
online piracy within India may increase substantially and more people may migrate to online piracy channels. The data from the empirical survey with regard to substantially high online piracy exposure among those who use Internet to watch movies points towards this future challenge. The percentage of respondents with exposure to streaming of pirated movies among the respondents who use internet to watch movies is found to be as high as $66.37 \%$ and the percentage of respondents with exposure to downloading is as high as $57.01 \% .^{66}$ It is only because the percentages of respondents who use to watch movies on Internet is found to be very low, the net percentages of respondents who have streamed or downloaded pirated movies online is found to be substantially low. ${ }^{67} \mathrm{With}$ affordable and better Internet connections, online piracy within India may also go up considerably. It would be in the long term interests of the industry to address the issue of online piracy and reduce the supply of pirated products before more consumers get acquainted with online pirated products.

Moreover, it is also important for the industry to recognize that by reaching the consumers abroad with legitimate product access options, they could substantially increase their revenues and thereby also increase the investments in quality and diversity of movies. The most important measure to be taken in this regard is decreasing the waiting period for providing legitimate access of movies to consumers abroad. As the information flow on the new movie releases were slow in the pre-digital era, the film industry could have earlier expected the consumers abroad to wait patiently for several months to watch a new movie. But the information revolution in the interconnected world has drastically reduced the information gaps about new movies. Today most consumers would prefer to watch a movie as soon as it is released domestically. The new digital technologies provide enormous scope for safe and fast transmission of movies to consumers across the world in different modes. For example, with the help of opportunities offered by the digital transmission technologies, the industry can increase the number of movies released in cinemas abroad. Similarly, IP location tracking tools enable the industry to release movies online, simultaneously with their domestic theatrical release or immediately afterwards, exclusively for consumers abroad. ${ }^{68}$ Such experiments would be particularly useful for movies from smaller regional film industries in India.

Another equally important measure to be taken is the collaboration within the industry for building affordable, easily searchable, and accessible

66. A screening question was included in the questionnaire to identify the respondents who used to watch movies online.

67. For example, among the respondents who have answered the question relating to streaming of pirated movies, only $28.75 \%$ used to watch movies online.

68. One of the very limited examples so far in this regard was the release of the bollywood movie Striker in an online platform exclusively for the international audience. It is estimated to have collected $\$ 100,000$ from streaming websites alone. See KPMG, supra note 32 , at 56 . 
databases of movies. This requires cooperation among movie producers with regard to licensing of their contents. Such databases should not only have movies from different regional languages, but also movies from different time periods. This is completely missing today. There are only very few legitimate streaming or downloading websites for Indian movies and most of them also perform poorly due to lack of proper indexing, high access prices, and lack of variety of movies.

On the other hand, one can see highly appreciable efficiency in the organising of contents in pirated movie platforms. Alphabetical/ year wise cataloguing of huge collection of movies from different regional film industries within India is one good example in this regard. In many cases one could also see their efforts for converting old analogue movies to digital formats. There are two important lessons in this regard. First, producers from different regional film industries within India could join hands and start new databases offering similar experiences for consumers within and outside India. Second, they could also try to negotiate with infringers for building revenue-sharing business models and convert the infringing platforms to legitimate access platforms. While such efforts would have many positive externalities for the society in general, including provision of alternate legitimate income for infringers, it could also save considerable money for the producers. This includes avoiding the costs involved in hosting movies online and avoiding the re-conversion of analogue prints to digital formats. In other words, instead of adopting the sole strategy of taking down the infringing online platforms legally or technologically, the industry may benefit more by adopting a strategy for collaboration. Any approach that merely focuses on taking down pirated media platforms, without providing consumers alternate legitimate channels, will only be opening roads for new infringing platforms to fill the vacuum.

Finally, the Indian film industry should also show willingness to follow the changing consumer preferences and try to adapt their business models to those changes. At present the industry is only pressurizing consumers to follow their age old business models through technological and legal protection measures. For example, many consumers today wish to watch new movies in the privacy and convenience of their portable digital devices or home. By not providing them the means to access movies in their preferred forms of consumption and by forcing them to watch movies only through conventional channels like cinemas and DVDs, the Indian film industry is trying to resist innovations in business practices. An interesting example to be noted in this regard is the huge resistance shown by cinema owners against the attempt of one of the most famous movie actor/ producer, Kamal Hassan, to release his latest movie "Viswaroopam" in DTH platforms. ${ }^{69}$ The cinema owners threatened to boycott the screening of

69. Theatre owners threaten against screening 'Viswaroopam', DECCAN HERALD, (Jan. 2, 2013), http://www.deccanherald.com/content/302552/theatre-owners-threaten-agains 
the movie in cinemas and the producer had to finally postpone the Direct-toHome (DTH) release of the movie. ${ }^{70} \mathrm{He}$ has approached the Competition Commission of India against the action taken by the cinema owners. ${ }^{71}$ But the most surprising part was the lack of open support from other producers within the industry for the novel attempt taken by this producer to experiment new mediums in view of the changing consumer preferences. If the industry fails to see the wider issue of changing consumption patterns, it may never be able to increase its revenues beyond theatrical revenues. The need of the time is innovative business practices that can meet the changing consumer expectations.

\section{CONCLUSION}

The Indian film industry has always played a significant role in influencing the evolution of copyright law in India. The new DRM provisions under the Indian copyright law are no exception in this regard. Under the influence of studies sponsored by the film and media industry, the Indian parliament has taken the view that online piracy is causing substantial loss to the Indian copyright holders and they have considered DRM provisions as the adequate solution to the problem. The Indian judiciary has also inadvertently supported this view by issuing many broadly worded orders that can affect the legitimate uses and users of Internet in India. As illustrated by this study through empirical data, Internet piracy may not be at a substantial level within India currently. The primary consumers of those pirated products might be the (potential) consumers abroad, who are deprived of access to legitimate channels for watching Indian movies. It is high time for the industry to evolve innovative business practices to reach those potential consumers, rather than solely relying on threats against those consumers through technological and legal measures. If the industry attempts to continue with their age old business models through legal and technological protection measures it may only deviate their (potential) consumers to other avenues of entertainment in the digital world.

t-screening.html.

70. DTH release of Viswaroopam on Feb 2, TIMES OF INDIA, (Jan. 15, 2013), http://articles.timesofindia.indiatimes.com/2013-01-15/news-interviews/36352393_1_dth-rel ease-dth-platform-dth-companies.

71. Kamal moves Competition Commission, THE Hindu, (Jan. 13, 2013), http://www .thehindu.com/arts/cinema/kamal-moves-competition-commission/article4302568.ece. 